\title{
Predictors of the Common Adverse Drug Reactions of Statins
}

\author{
Hadeer Akram AbdulRazzaq1, Noorizan Abd Aziz², Yahaya Hassan², \\ Yaman Walid Kassab ${ }^{1}$ and Omar Ismail ${ }^{3}$ \\ ${ }^{1}$ Department of Clinical Pharmacy, School of Pharmaceutical Sciences, \\ Universiti Sains, Penang, \\ ${ }^{2}$ Faculty of Pharmacy, UiTM, Puncak Alam Campus, \\ Bandar Puncak Alam, Selangor DE, \\ ${ }^{3}$ Department of Cardiology, Hospital Pulau Pinang, Penang, \\ Malaysia
}

\section{Introduction}

Statins are common lipid lowering agents to reduce elevation of cholesterol or as prophylaxis against other cardiac diseases. It estimated that $62.5 \%$ to $91.7 \%$ of dyslipidemic patients in United State of America are using statins ${ }^{1}$ These agents widely used among cardiovascular patients in Malaysia ${ }^{2}$. In other countries, for example in UK, it has found that most patients who use statins are older than 35 years old and more of them are males $(56 \%)^{3}$. In Canada, about $90 \%$ of cardiac patients are using statin, while in US, at least one third of all cardiac patients are using statins ${ }^{4}$. About $60 \%$ of American patients who older than 60 years old are using statin ${ }^{5}$. Thus, high number of users contributed to increase the risk of adverse drug reactions (ADRs).

The Food and Drug Administration (FDA) has determined that common statin-associated ADRs are fatigue, muscle pain, joints pain, back pain, visual disturbance and insomnia 6,7 . Previous studies have examined the incidence of these ADRs, and their results showed that more than half of the reported cases of muscle pain were related to statin use ${ }^{8,9}$. Clearfield et al found that fatigue, muscle pain, and bone pain were common and frequent ADRs in UK, and related to atorvastatin and rosuvastatin use ${ }^{10}$. Other studies exploring ADRs in patients using atorvastatin and lovastatin in the US found that muscle pain and fatigue were the most common statin-related ADRs ${ }^{11}$. The UK Committee on Safety of Medicines, as well as other studies, have reported that these symptoms should consider as early signs for more serious ADRs $8,12-15$. However, from our knowledge, no data available on the common ADRs statin-related and their predictors for Asian patients. Only a few studies (not related with Asian patients) have found out the predictors of the statin-related ADRs $8,9,10,16,17$. As health care professional, they should find methods to ensure patients not only receive effective medication but also feel comfortable with the therapy. Thus, the objectives of this study was to determine the common statin-related ADRs and their predictors in one of the referral hospital in Malaysia (one of country in South East Asia). 


\section{Method}

Cross-sectional with convenient sampling study conducted for volunteer outpatients from the cardiac clinic of Penang Hospital in Pulau Pinang State of Malaysia. Study protocol was approved by Clinical Research Committee of Penang General Hospital, and signed consent forms were obtained from all participants. The patients included in this study were at least 18 years old and voluntarily to participate in this study. They have to used statins and could understand Malay Language (the National Language of Malaysia) or English Language, since Malaysia is a multiracial country. Patients who allergies to statin, pregnant or lactating women, or changing in types or dosage of statin used were excluded from this study. These types of patients excluded because their conditions may affected outcomes of the study. The study period was 5 months, and 1900 patients presented in the cardiac clinic within this study period. Depending on inclusion and exclusion criteria, 500 patients voluntarily agreed to participate in this study. A validated questionnaire form (Cronbach's alpha is 0.853) were used for reporting of ADRs. The patients were asked whether they have experience of common statin-related ADRs while they were on statin therapy and give their answers on the self-report questionnaire forms. This questionnaire form has some questions on demographic data and undesired symptoms that patients had during statin therapy. There were 27 ADRs of statin listed in the questionnaire form. They were required to tick yes or no on these listed ADRs. They can tick more than one ADR. In order to ensure these ADRs really related with statin therapy these patients had to indicate in the questionnaire form that these ADRs occurred while they were receiving statin therapy and these symptoms should continuously occurred at least for 3 months.

\section{Statistics}

Statistical Package for Social Science software (SPSS) version 18 used to analyze the data for this study. Odd ratio and Chi-square and logistic regression tests were used to ensure these ADRs were related with stain therapy and to determine their predictors. The results with $p$ value less than 0.05 was considered statistically significant.

\section{Results}

Male patients $(70 \%)$ were the more frequent users of statins, with mean age $60 \pm 10$ years. The most frequent race that used statins was Chinese (37.6\%), followed by Malays $(34.4 \%)$, Indians $(26.6 \%)$ and foreigners $(1.4 \%)$. Small numbers of patients were cigarette smoker (12\%) and alcohol consumers (9\%).

Higher number of patients had dyslipidemia with primary type $(51.5 \%)$ based on the Friedewald et $\mathrm{al}^{18}$ and Stone et $\mathrm{al}^{19}$ classifications. For primary subtypes of dyslipidemia, the most common subtype was IIa $(50.6 \%)$, while common subtype of secondary dyslipidemia was diabetes $(86.3 \%)$. The common type of statin used was lovastatin $(81 \%)$, followed by simvastatin $(9.4 \%)$ and atorvastatin $(8 \%)$. The low dose $(20 \mathrm{mg})$ of statin was the common prescribed to these patients. The mean duration of statin therapy was 3.5 years and the most frequent range of duration was $1-5$ years $(52.5 \%)$, as shown in Table 1.

Statistical regression analysis was used to exclude symptoms related to other medications and diseases. It found only few symptoms from 27 ADRs that correlated significantly with statins were; fatigue $(59.4 \%)$, muscle pain $(53.6 \%)$, joint pain $(53.4 \%)$, back pain $(47.8 \%)$, insomnia $(44.8 \%)$ and visual disturbances $(44.2 \%)$. 


\begin{tabular}{|c|c|c|}
\hline Demographics & Variables & No $(\%)$ \\
\hline \multirow[t]{2}{*}{ Gender } & Male & $351(70 \%)$ \\
\hline & Female & $149(30 \%)$ \\
\hline \multirow[t]{4}{*}{ Race } & Malay & $172(34.4 \%)$ \\
\hline & Chinese & $188(37.6 \%)$ \\
\hline & Indian & $133(26.6 \%)$ \\
\hline & Foreign & $7(1.4 \%)$ \\
\hline \multirow[t]{3}{*}{ Age (mean $60 \pm 10$ )year } & 28-50 year & $94(19 \%)$ \\
\hline & 51-65 year & $258(51 \%)$ \\
\hline & $66-92$ year & $148(30 \%)$ \\
\hline \multirow[t]{2}{*}{ Smoke } & Yes & $59(12 \%)$ \\
\hline & No & $441(88 \%)$ \\
\hline \multirow[t]{2}{*}{ Alcohol consuming } & Yes & 47 (9\%) \\
\hline & No & $453(91 \%)$ \\
\hline \multirow[t]{2}{*}{ Dyslipidiemia type } & Primary & $247(51.5 \%)$ \\
\hline & Secondary & $233(48.5 \%)$ \\
\hline \multirow{6}{*}{$\begin{array}{l}\text { Primary dyslipidemia } \\
\text { subtype }\end{array}$} & I & $13(5.3 \%)$ \\
\hline & IIa & $125(50.6 \%)$ \\
\hline & $\mathrm{IIb}$ & $59(23.9 \%)$ \\
\hline & III & $7(2.8 \%)$ \\
\hline & IV & $32(13 \%)$ \\
\hline & $\mathrm{V}$ & $11(4.5 \%)$ \\
\hline \multirow{6}{*}{$\begin{array}{l}\text { Secondary } \\
\text { dyslipidemia subtype }\end{array}$} & Renal & $17(7.3 \%)$ \\
\hline & Diabetes & $201(86.3 \%)$ \\
\hline & Nephrotic syndrome & $1(0.4 \%)$ \\
\hline & Liver & $1(0.4 \%)$ \\
\hline & Drugs & $2(0.9 \%)$ \\
\hline & Hypothyroidism & $11(4.7 \%)$ \\
\hline \multirow[t]{4}{*}{ Type of statin } & Atorvastatin & $40(8 \%)$ \\
\hline & Simvastatin & $47(9.4 \%)$ \\
\hline & Lovastatin & $405(81 \%)$ \\
\hline & others & $8(1.6)$ \\
\hline \multirow[t]{2}{*}{ Combination therapy } & Yes & $35(7 \%)$ \\
\hline & No & $465(93 \%)$ \\
\hline Duration of therapy & 3 months or less & $16(3.2 \%)$ \\
\hline \multirow[t]{3}{*}{ Mean $(3.5 \pm 3.0)$ year } & 3months -1 year & $133(26.7 \%)$ \\
\hline & $1-5$ years & $262(52.5 \%)$ \\
\hline & 5-20 years & $89(17.6 \%)$ \\
\hline
\end{tabular}

Table 1. Demographic data of 500 cardiac outpatients in Penang General Hospital 


\begin{tabular}{|c|c|c|c|c|c|c|}
\hline \multirow[t]{2}{*}{ Predictors } & \multicolumn{6}{|c|}{ ADRs (percentage, P value, $\mathrm{OR}, \mathrm{CI}$ ) } \\
\hline & Fatigue & $\begin{array}{l}\text { Muscle } \\
\text { pain }\end{array}$ & Joint pain & Back pain & Insomnia & $\begin{array}{l}\text { Visual } \\
\text { disturb- } \\
\text { ances }\end{array}$ \\
\hline $\begin{array}{l}\text { Gender } \\
\text { (female) }\end{array}$ & NS & NS & $\begin{array}{l}61.74 \%, \\
\mathrm{P}=0.007, \\
\mathrm{OR}= \\
1.864, \mathrm{CI}= \\
1.18-2.94\end{array}$ & $\begin{array}{l}56.38 \% \\
P=0.02, \\
O R=1.73 \\
C I=1.09- \\
2.75\end{array}$ & NS & NS \\
\hline $\begin{array}{l}\text { Race } \\
\text { (Indian) }\end{array}$ & $\begin{array}{l}68.42 \%, \\
\mathrm{P}=0.027, \\
\mathrm{OR}=1.81, \\
\mathrm{CI}=2.14- \\
2.75)\end{array}$ & $\begin{array}{l}66.92 \% \\
P=0.016 \\
O R=1.94 \\
C I=1.13- \\
3.32)\end{array}$ & NS & $\begin{array}{l}62.4 \% \\
P=0.007 \\
O R=2.18 \\
C I=1.23- \\
3.72\end{array}$ & NS & $\begin{array}{l}49.62 \%, \\
\mathrm{P}=0.016, \\
\mathrm{OR}=1.74, \\
\mathrm{CI}=1.11- \\
2.73)\end{array}$ \\
\hline Smokers & NS & NS & NS & NS & NS & NS \\
\hline Alcoholic & $\begin{array}{l}76.60 \% \\
P=0.011 \\
O R=3.0 \\
C I=1.29- \\
7.01)\end{array}$ & NS & NS & $\begin{array}{l}65.96 \% \\
P=0.003 \\
O R=3.58 \\
C I=1.53- \\
8.38\end{array}$ & $\begin{array}{l}59.57 \%, \\
P=0.006, \\
O R=2.89, \\
C I=1.36- \\
6.15\end{array}$ & NS \\
\hline Age & NS & NS & NS & NS & NS & NS \\
\hline $\begin{array}{l}\text { Duration } \\
\text { More than } \\
5 \text { years }\end{array}$ & $\begin{array}{l}53.41 \% \\
\mathrm{P}=0.036 \\
\mathrm{OR}=1.83 \\
\mathrm{CI}=1.04- \\
3.23)\end{array}$ & $\begin{array}{l}60.23 \%, \\
P=0.016, \\
O R=1.96 \\
C I=1.133- \\
3.39\end{array}$ & NS & $\begin{array}{l}57.95 \%, \\
\mathrm{P}=0.001, \\
\mathrm{OR}=2.61, \\
\mathrm{CI}=1.50- \\
4.54)\end{array}$ & NS & NS \\
\hline $\begin{array}{l}\text { Primary } \\
\text { subtypes } \\
\text { (type IIb) }\end{array}$ & NS & NS & NS & $\begin{array}{l}33.90 \% \\
P=0.014 \\
O R=2.50 \\
C I=1.21- \\
5.19)\end{array}$ & NS & NS \\
\hline $\begin{array}{l}\text { Secondary } \\
\text { subtypes } \\
\text { (renal } \\
\text { disease) }\end{array}$ & NS & NS & NS & NS & $\begin{array}{l}64.71 \% \\
\mathrm{P}=0.33 \\
\mathrm{OR}=3.7 \\
\mathrm{CI}=1.11- \\
12.33\end{array}$ & NS \\
\hline Statin types & NS & NS & NS & NS & NS & NS \\
\hline $\begin{array}{l}\text { Atorvastatin } \\
\text { doses } \\
(20 \mathrm{mg})\end{array}$ & NS & NS & NS & NS & NS & NS \\
\hline
\end{tabular}




\begin{tabular}{|c|c|c|c|c|c|c|}
\hline $\begin{array}{l}\text { Simvastatin } \\
\text { dose } \\
(40 \mathrm{mg})\end{array}$ & NS & NS & NS & NS & NS & NS \\
\hline $\begin{array}{l}\text { Lovastatin } \\
\text { doses } \\
(60 \mathrm{mg})\end{array}$ & $\begin{array}{l}72.73 \% \\
\mathrm{P}=0.003 \\
\mathrm{OR}=1.90 \\
\mathrm{CI}=1.25- \\
2.89)\end{array}$ & NS & NS & NS & NS & NS \\
\hline $\begin{array}{l}\text { Combination } \\
\text { therapy }\end{array}$ & NS & NS & NS & NS & NS & NS \\
\hline
\end{tabular}

NS= no significant

Table 2. Relationship between statin related ADRs and predictors

In term of predictor, females significantly had joint pain $(61.74 \%, \mathrm{OR}=1.864)$ and back pain $(56.38 \%$, OR $=1.73)$. However, there was no significant relation between gender with fatigue, muscle pain, insomnia and visual disturbance. Indian patients had significantly higher incidence of fatigue $(68.42 \%, \mathrm{OR}=1.81)$, muscle pain $(66.92 \%, \mathrm{OR}=1.94)$, back pain $(62.4 \%, \mathrm{OR}=2.18)$, and visual disturbances $(49.62 \%, \mathrm{OR}=1.738)$ when compared to other races. No significant relationship found between smoking and statin related-ADRs. Patients who consumed alcohol significantly had fatigue $(76.6 \%$, OR $=3.0)$, back pain $(65.96 \%$, OR $=$ 3.584 ) and insomnia $(59.57 \%$, OR $=2.893)$. Age was without effect on incidence of statin related-ADRs. Patients used statins for more than 5 years significantly had fatigue $(53.41 \%$, $\mathrm{OR}=1.83)$ and muscle pain $(60.23 \%, \mathrm{OR}=1.958)$, as shown in Table 2 .

For secondary dyslipidemia types, renal induced dyslipidemia significantly caused higher incidence of insomnia when compared to the other secondary subtypes $(64.71 \%$, OR $=3.7)$. For subtypes of primary dyslipidemia, subtype IIb patients had significantly back pain $(81.82 \%, \mathrm{OR}=2.5)$.

No significant relationship found between statin related-ADRs and statin types, the patients used simvastatin had a higher incidence of fatigue (65.96\%), joint pain $(57.45 \%)$, back pain (55.32\%) and visual disturbance (53.19\%). Patients used lovastatin had insomnia $(45.68 \%)$, while patients used atorvastatin had higher incidence of muscle pain $(52.17 \%)$. No significant relationship found between doses of statins and other ADRs except for lovastatin dose. Patients used $60 \mathrm{mg}$ dose of lovastatin had significantly fatigue than patients used lower doses $(72.73 \%$, OR $=1.904)$. No significant relation found between the combination with other lipid lowering agents and incidence of ADRs (as shown in Table 2).

\section{Discussion}

After two decades of statin marketing, significant incidences of adverse drug reactions still presented during therapy. Number of studies of medications' ADRs always increased after first years of launching, but it found this matter is different with type of statin used ${ }^{20}$. Most of previous studies focused on serious ADRs of statin like muscle toxicity, elevation of liver enzymes, renal toxicity and polyneuropathy ${ }^{21,22}$. Although serious ADRs caused mortalities and death to patients, but their incidences are lower than other adverse reactions of statin 
symptomatic related ADRs. Kashani A. et al. ${ }^{23}$ found that incidences of patients discontinued their therapy because of symptomatic ADRs of statin (5.6\%) were higher than patients had rhabdomyolysis $(0.2 \%)$, hepatotoxicity $(1.4 \%)$, and creatine kinase (CK) elevations $(0.9 \%)$. Therefore, self-reporting of ADRs are useful to determine and predict the toxicities induced by medication ${ }^{24}$. There are few studies done on the common statin-related ADRs that use patient self-report. There was a previous study that focused on the common ADRs during statin therapy and their predictors in cardiac outpatients. They reported the use of a self-report questionnaire form is suitable approach to assess the common undesired symptoms found during statin therapy ${ }^{25}$. In the real-life practice, doctors are more focusing on dyslipidemia and its complications than statin-related ADRs of their patients. Furthermore, self-report approach allows the patients to express directly their unwanted problems associated with statin therapy. In addition, patients sometimes feel uncomfortable or inappropriate telling their doctor about these undesired symptoms of $\operatorname{statin}^{26,27}$. The finding in this study showed a higher incidence of fatigue and muscle pain in this cardiac outpatients setting, which consistent with previous studies 8,10 .

In this study, females reported having back and joint pain significantly more than males did. Female patients are more sensitive to ADRs than males possibly because of pharmacokinetic and pharmacodynamic differences between genders ${ }^{28}$. Not all ADRs of statin related to gender, this finding supported by FDA, Bayer reports and previous studies29-32. When compared to other races, Indian patients had significantly higher incidence of some common ADRs (fatigue, muscle pain, back pain and visual disturbance). This is because genetics also has contributed in adverse drug reactions ${ }^{23}$. This result was supported by FDA reports in which ADRs were different among races7. Cigarette smokers had increased incidence of these ADRs than nonsmokers, however this finding was not statistically significant. Alcohol consumers had significant problems with fatigue, back pain and insomnia, and increased incidence of ADRs in general ${ }^{30}$. This is because alcohol causes mitochondrial dysfunction, which would increase the risk of muscle disorders caused by statins ${ }^{33}$. There was no relationship between age and ADRs, as shown in Table 2, which supported by Kucukarslan et al study ${ }^{34}$. There was a relationship between duration of statin used and ADRs in previous studies $29,35,36$. Their finding were consistent with this present finding, where the duration of statin therapy has related to fatigue, muscle pain and back pain.

Based on our knowledge, no previous studies reported the relationship between dyslipidemia types and the common ADRs. Significant relationship was found in this study between dyslipidemia type (primary and secondary) and common ADRs. Patients who had secondary dyslipidemia type had increase frequency of insomnia than with primary type. Patients with subtype IIb and renal induced dyslipidemia were significantly more likely to have back pain and insomnia than other subtypes.

Although statins differ in their pharmacokinetic properties 37,38 , there is no significant relationship found between statin types and common ADRs. However, simvastatin was more likely to cause fatigue, joint pain, back pain and visual disturbance than other statins. Although there is no significant relation found between atorvastatin and common ADRs. Atorvastatin found to cause muscle pain more often than other statin types, this finding also proved by Clearfield et al. and Golomb et al. 10,11. Patients on lovastatin therapy had higher incidence of insomnia than other types of statin. Higher doses for all types of statins have resulted in a higher incidence of ADRs. The higher dose of lovastatin $(60 \mathrm{mg})$ significantly 
associated with fatigue. The dose of statins used did not have significant relationship with other symptoms of common ADRs. This result is consistent with other studies ${ }^{12,39}$. Finally, there was no significant relationship between combination therapy and ADRs. This relationship could not be seen possibly due to small number of patients receiving more than one type of antilipidemic agent.

The finding of this study showed that significant number of patients feel undesired effects of statin therapy and their predictors. Adjustment or manipulating of these preventable predictors such as to change type of statin used, reduce dose and duration are recommended to the prescribers. For example, based on the odd ratio, fatigue was the highest for patients who are alcohol consumers, followed by lovastatin dosage, duration and race. Therefore, steps needed to reduce the incidence of fatigue by avoiding or reducing the preventable predictors that related to these common ADRs like cessation of alcohol and changing in type or dose of statin used.

\section{Conclusion}

This paper explained that significant number of cardiac outpatients were experienced common ADRs related-statin through self-report approach and their predictors. Common ADRs of statin were fatigue, muscle pain, joint pain, back pain, insomnia and visual disturbances. The main predictors or contributing factors of common statin-related ADRs were gender, race, alcohol consumption, duration of statin used, renal induced-secondary dyslipidemia, subtype IIb of primary dyslipidemia and lovastatin dose. These predictors are useful in clinical practice to determine the likelihood of ADRs and to manage the common ADRs of statin in cardiac outpatients. Finding from this study was suggested appropriate dose and type of statin use and also adjustment of the preventable predictors may minimize common ADRs of statin in cardiac outpatients. Appropriate prospective study design with multicenter sites recommended determining the actual effects of these preventable predictors on common ADRs of statin.

\section{References}

[1] Avorn J, Monette J, Lacour A, Bohn RL, Monane M, Mogun H, LeLorier J.(1998). Persistence of Use of Lipid-Lowering Medications: a cross-national study. Journal of the American Medical Association 279:1458-1462

[2] National Cardiovascular Disease Database (NCVD) (2006), Malaysia

[3] Dewilde S, Carey IM, Bremner SA, Richards N, Hilton SR, Cook DG (2003). Evolution of statin prescribing 1994-2001: a case of agism but not of sexism? Heart 89:417-421

[4] National Cholesterol Education Program (NCEP) (2002). Expert panel on detection, evaluation, and treatment of high blood cholesterol in adults (adult treatment panel III). Third report of the national cholesterol education program (NCEP) expert panel on detection, evaluation, and treatment of high blood cholesterol in adults (Adult Treatment Panel III) final report 106:3143-3421

[5] Farahani P, Gaebel K, Lelorier J, Perrault S, Gillis J, Soon J, Levine M (2005). Assessment of patient characteristics associated with statin use. The Canadian Journal of Clinical Pharmacology 12: e41-e149: 31 
[6] AHFS (2007). HMG-CoA Reductase Inhibitors (Statins) - Safety Overview. Drug Information Service, University of Utah.

[7] U.S food and drug administration: Rosuvastatin Calcium (marketed as Crestor) Information Patient information sheet. (2005) [Online]. [10 ${ }^{\text {th }}$ March 2008] available from World Wide Web:

http://www.fda.gov/cder/drug/ infopage/rosuvastatin/default.htm

[8] Thompson PD, Clarkson P, Karas RH. (2003). Statin associated Myopathy. Journal of the American Medical Association 289:1681-1690

[9] Ballantyne CM, Corsini A, Davidson MH, Holdaas H, Jacobson TA, Lieitersdorf E, Marz W., Reckless, J PD, Stein EA (2003). Risk for myopathy with statin therapy in highrisk patients. Archive of Internal Medicine 163: 553-564.

[10] Clearfield MB, Amerena J, Bassand JP, Hernández García HR, Miller SS, Sosef FF, Palmer MK and Bryzinski BS (2006). Comparison of the efficacy and safety of rosuvastatin $10 \mathrm{mg}$ and atorvastatin $20 \mathrm{mg}$ in high-risk patients with hypercholesterolemia - prospective study to evaluate the use of low doses of the statins atorvastatin and rosuvastatin (PULSAR). Licensee Biomed Central Ltd. Trial 7:35

[11] Golomb BA, Yang E, Denenberg J, Criqui M (2003). Statin-associated adverse events. Circulation 107; e7001-e7039, 95

[12] Pasternak RC, Smith SCJ, Bairey-Merz CN, Grundy SM, Cleeman JI, Lenfant C (2002). ACC/AHA/NHLBI Clinical advisory on the use and safety of statins. Journal of the American College of Cardiology 106: 567-572

[13] Hamilton CI (2003). Statins and muscle damage. Australian Prescriber 26:74-75

[14] Gaist D, Jeppesen U, Andersen M, García Rodríguez LA, Hallas J, Sindrup SH (2002). Statins and risk of polyneuropathy: a case-control study. Neurology 14; 58(9):1321-2.

[15] Committee on safety of medicines (2001). Cerivastatin (lipobay) withdrawn. Current Problem in Pharmacovigillance 27: 9

[16] Shepherd J, Cobbe SM, Ford I, Isles CG, Lorimer AR, MacFarlane PW, McKillop JH, Packard CJ (1995). Prevention of coronary heart disease with pravastatin in men with hypercholesterolemia. West of Scotland Coronary Prevention Study Group (WOSCOPS). The New England Journal of Medicine 333:1301-1307

[17] Cheryl A (2007). HMG-CoA Reductase Inhibitors/Statins, PHARMD, UCSF School of Pharmacy, University of California at San Francisco.

[18] Friedewald WT, Levy RI, Fredrickson DS (1972). Estimation of the concentration of lowdensity lipoprotein cholesterol in plasma without use of the preparative ultracentrifuge. Clinical Chemistry 18:499-502.

[19] Stone NJ and Blum CB (2008). Management of Lipids in Clinical Practice. Professional Communications p80

[20] Brown WV (2008). Safety of statins. Curr Opin Lipidol 19(6):558-62

[21] Zipes DP, Zvaifler NJ, Glassock RJ, Gilman S, Muñoz A, Gogolak V, Gordis L, Dedon PC, Guengerich FP, Wasserman SI, Witztum JL, Wogan GN (2006). Rosuvastatin: an independent analysis of risks and benefits. MedGenMed 8(2):73. 
[22] Silva MA, Swanson AC, Gandhi PJ, Tataronis GR (2006). Statin-related adverse events: a meta-analysis. Clin Ther 28(1):26-35.

[23] Kashani A, Phillips CO, Foody JM, Wang Y, Mangalmurti S, Ko DT, Krumholz HM (2006). Risks associated with statin therapy: a systematic overview of randomized clinical trials. Circulation 114(25):2788-97.

[24] Grundy SM (2005). The issue of statin safety: where do we stand? Circulation 111:30163019

[25] Gholami K., Ziaie S., and Shalviri G (2008). Adverse drug reactions induced by cardiovascular drugs in outpatients. Pharmacy Practice 6(1):51-55.

[26] Golomb BA, Kane T and Dimsdale JE (2004). Severe irritability associated with statin cholesterol-lowering agents. The Quarterly Journal of Medicine 97:229-235.

[27] Golomb BA, Mcgraw JJ, Evans MA and Dimsdale JE (2007). Physician response to patient reports of adverse drug effects. Drug Safety 30(8): 669-675.

[28] Sigonda N (2003). guidelines for monitoring and reporting adverse drug reactions (ADRs) made under section 5 (c) of the Tanzania food, drugs and cosmetics Act 2003

[29] Alsheikh-Ali AA, Ambrose MS, Kuvin JT, Karas RH (2005). The safety of rosuvastatin as used in common clinical practice: a postmarketing analysis. Circulation 111:30513057.

[30] Hanston PD, and Horn JR (1998). Drug interactions with HMG CoA reductase inhibitors. Drug Interactions Newsletter 103-6

[31] EMEA (2002) Scientific conclusion and ground for withdrawal of the marketing authorization presented, CPMP/811/02

[32] Gray SL, Mahoney JE, Blough DK (1999). Adverse drug events in elderly patients receiving home health services following hospital discharge. The Annals of Pharmacotherapy 33:1147-1153

[33] Mabuchi H, Nohara A, Kobayashi J, Kawashiri MA, Inazu A (2007). Coenzyme Q10 Reduction with Statins: Another Pleiotropic Effect Current Drug Therapy 2: 39-51

[34] Kucukarslan SN, Peters M, Mlynarek M, Nafziger DA (2003). Pharmacists on rounding teams reduce preventable adverse drug events in hospital general medicine units. Arch Intern Med 22;163(17):2014-8.

[35] Corrao G, Zambon A, Bertù L, Botteri E, Leoni O, Contiero P (2004). Lipid lowering drugs prescription and the risk of peripheral neuropathy: an exploratory casecontrol study using automated databases. Journal of Epidemiology Community Health 58:1047-1051.

[36] Agostini JV, Tinetti ME, Ling H, Mcavay G, Foody JM and Concato J (2007). Effects of Statin use on muscle strength, Cognition, and Depressive Symptoms In older adults. The American Journal of Geriatric Cardiology in Society 55:420-425

[37] Jones P, Kafonek S, Laurora I, Hunninghake D (1998). Comparative dose efficacy study of atorvastatin versus simvastatin, pravastatin, lovastatin, and fluvastatin in patients with hypercholesterolemia (The Curves Study). The American Journal of Cardiology 81:582-587 
[38] Corsini A, Bellosta S, Baetta R, Fumagalli R, Paoletti R, Bernini F (1999). New insights into the pharmacodynamic and pharmacokinetic properties of statins. Pharmacology and Therapeutic 84:413-428

[39] Ravnskov U, Rosch PJ, Sutter MC, Houston MC (2006). Should we lower cholesterol as much as possible? BMJ 332(7553):1330-1332. 


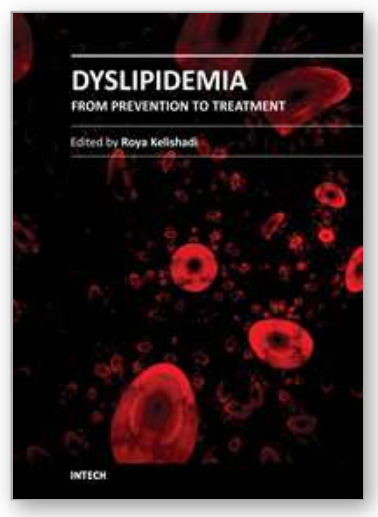

\author{
Dyslipidemia - From Prevention to Treatment \\ Edited by Prof. Roya Kelishadi
}

ISBN 978-953-307-904-2

Hard cover, 468 pages

Publisher InTech

Published online 03, February, 2012

Published in print edition February, 2012

Dyslipidemia has a complex pathophysiology consisting of various genetic, lifestyle, and environmental factors. It has many adverse health impacts, notably in the development of chronic non-communicable diseases. Significant ethnic differences exist due to the prevalence and types of lipid disorders. While elevated serum total- and LDL-cholesterol are the main concern in Western populations, in other countries hypertriglyceridemia and low HDL-cholesterol are more prevalent. The latter types of lipid disorders are considered as components of the metabolic syndrome. The escalating trend of obesity, as well as changes in lifestyle and environmental factors will make dyslipidemia a global medical and public health threat, not only for adults but for the pediatric age group as well. Several experimental and clinical studies are still being conducted regarding the underlying mechanisms and treatment of dyslipidemia. The current book is providing a general overview of dyslipidemia from diverse aspects of pathophysiology, ethnic differences, prevention, health hazards, and treatment.

\title{
How to reference
}

In order to correctly reference this scholarly work, feel free to copy and paste the following:

Hadeer Akram AbdulRazzaq, Noorizan Abd Aziz, Yahaya Hassan, Yaman Walid Kassab and Omar Ismail (2012). Predictors of the Common Adverse Drug Reactions of Statins, Dyslipidemia - From Prevention to Treatment, Prof. Roya Kelishadi (Ed.), ISBN: 978-953-307-904-2, InTech, Available from:

http://www.intechopen.com/books/dyslipidemia-from-prevention-to-treatment/predictors-of-the-commonadverse-drug-reactions-of-statins

\section{INTECH}

open science | open minds

\section{InTech Europe}

University Campus STeP Ri

Slavka Krautzeka 83/A

51000 Rijeka, Croatia

Phone: +385 (51) 770447

Fax: +385 (51) 686166

www.intechopen.com

\section{InTech China}

Unit 405, Office Block, Hotel Equatorial Shanghai

No.65, Yan An Road (West), Shanghai, 200040, China

中国上海市延安西路65号上海国际贵都大饭店办公楼405单元

Phone: +86-21-62489820

Fax: +86-21-62489821 
(C) 2012 The Author(s). Licensee IntechOpen. This is an open access article distributed under the terms of the Creative Commons Attribution 3.0 License, which permits unrestricted use, distribution, and reproduction in any medium, provided the original work is properly cited. 